\title{
Farmed cod escapees and net-pen spawning left no clear genetic footprint in the local wild cod population
}

\author{
Rebekka Varne ${ }^{1, *}$, Kristina L. Kunz ${ }^{1,4}$, Torild Johansen ${ }^{2}$, Jon-Ivar Westgaard ${ }^{2}$, \\ Ingebrigt Uglem ${ }^{3}$, Jarle Mork ${ }^{1}$ \\ ${ }^{1}$ Trondhjem Biological Station, Department of Biology, Norwegian University of Science and Technology, 7491 Trondheim, \\ Norway \\ ${ }^{2}$ Institute of Marine Research, Sykehusveien 23, 9294 Tromsø, Norway \\ ${ }^{3}$ Norwegian Institute for Nature Research, Høgskoleringen 9, 7034 Trondheim, Norway \\ ${ }^{4}$ Present address: Alfred Wegener Institute, Helmholtz Centre for Polar and Marine Research, Am Alten Hafen 26, \\ 27568 Bremerhaven, Germany
}

\begin{abstract}
This study investigated a potential genetic introgression from farmed to wild cod Gadus morhua L. in the Trondheimsfjord, Norway. During the first $2 \mathrm{yr}$ of operation of a cod farm in the inner part of the fjord, 2 large escape events and extensive pen spawning were reported. Analyses of 4 allozyme markers revealed no significant changes in allele frequencies between samples of wild cod before and after cod farming, although prominent allele frequency differences were demonstrated between wild and farmed samples. Analyses of 10 DNA markers showed a significant change between pre- and post-farming samples, due to contradictory allele frequency differences at Tch11, Pan I and Gmo132. Excluding those 3 markers due to null alleles (Tch11) and selection (Gmo132 and Pan I), the DNA markers paralleled the non-changed allele frequency signal from the allozymes. The topographies of the allozyme- and DNA-based dendrogram of the samples were congruent. Recaptures of tagged and released farmed cod indicated a seemingly random diffusion throughout the fjord and ended after approx. 6 mo. During an ongoing pen spawning, plankton net surveys sampling for cod eggs in the surroundings of the cod farm suggested the eggs originated from the farm. No larvae were present in the plankton samples. The apparent absence of introgression is explained relative to fitness and survival of pen-spawned larvae and adult escapees, and to a purging effect of the estuarine circulation of the Trondheimsfjord.
\end{abstract}

KEY WORDS: Atlantic cod · Gadus morhua $\cdot$ Aquaculture $\cdot$ Escapes $\cdot$ Introgression · Microsatellite DNA · Allozymes

\section{INTRODUCTION}

Commercial farming of cod Gadus morhua L. in net pens has a relatively short history in Norway, starting with a small-scale operation ca. 1990, but not reaching a substantial quantity before 2002 (Statistics Norway 2013). Frequent pen wreckage and escape incidents raised the similar concerns to those with salmonid aquaculture regarding harmful effects of genetic intro-

\footnotetext{
*Corresponding author: rebekka.varne@ntnu.no
}

gression by escapees into locally adapted wild populations (Bekkevold et al. 2006, Moe et al. 2007). These concerns are supported by the findings that adult escaped cod have appeared on the spawning grounds of wild relatives (Wroblewski et al. 1996, Uglem et al. 2008), and that escapees may take part in the annual reproduction process (Meager et al. 2010). In addition, and in contrast to salmonids, cod are known to spawn in the net pens (Uglem et al. 2012). Furthermore, in the restricted. Authors and original publication must be credited. 
landlocked fjord Heimarkspollen near Bergen, Norway, cod larvae from net-pen spawning were found up to $8 \mathrm{~km}$ from the net pen (Jørstad et al. 2008), thus representing a potential genetic introgression of farmed cod into natural cod populations (Bekkevold et al. 2006, Jørstad et al. 2008, Glover 2010, Uglem et al. 2012). Jørstad et al. (2013) showed that genetically marked cod dispersed throughout a fjord system, and documented the presence of juveniles and successful reproduction either by spawning in net pens or by escapees participating on local spawning grounds. Farmed cod showed substantial genetic differences between farm cohorts and among farms, a feature which potentially can be used for identification of escaped cod (Glover et al. 2010). In late 2007, a cod farming facility was established in the inner part of the Trondheimsfjord (Fig. 1A). In December 2008 and September 2009, the cod farm experienced 2 major escape events due to pen wreckage, in which 25000 and 42000 individuals escaped, respectively (Norwegian Directorate of Fisheries 2009) (Fig. 2). In less than 1 yr the number of cod which escaped was comparable to the annual number of natural spawners in the fjord, as estimated by Sundnes (1980). The cod farm was operational until April 2010, and was the first and so far only cod farm in the fjord. For the first time, large amounts of adult cod of a nonindigenous origin had both spawned in net pens and escaped to the genetically well characterized Trondheimsfjord cod population. Genetic and biological characteristics of the Trondheimsfjord cod stock have been monitored thoroughly in a time series maintained by the Trondhjem Biological Station (TBS) since 1974 (Mork 1976, Mork et al. 1980, 1982, 1983, 1985, Mork \& Sundnes 1985, Mork \& Giæver 1999, Karlsson \& Mork 2003, 2005). The present experimental conditions allowed both the monitoring of pen spawning and the set-up of a simulated escape event with tagged farmed cod for monitoring of recaptures. We hypothesized that by using the genetic characterization of the farmed cod, the level of genetic introgression might be estimated by comparing the genetic characteristics of the wild cod stock before and after cod farming in the fjord. Whether escapes from commercial scale farms result in changes in the genetic composition of wild stocks has not been examined in Norway yet.

\section{MATERIALS AND METHODS}

The Trondheimsfjord (Fig. 1A) is situated in midNorway and is the third longest and seventh deepest fjord in Norway. Based on results from previous tagging-recapture experiments (Sundnes 1980) and population genetic studies (Mork et al. 1983, 1985, Karlsson \& Mork 2005), the cod in the Trondheimsfjord proper is regarded as a largely self-recruiting stock which receives and exports very few adult individuals to adjacent coastal areas. The main spawning area is located in the inner areas including Verrasundet (Mork et al. 1982), and the nursery areas of juveniles cover most of the shallow parts of the fjord, including the
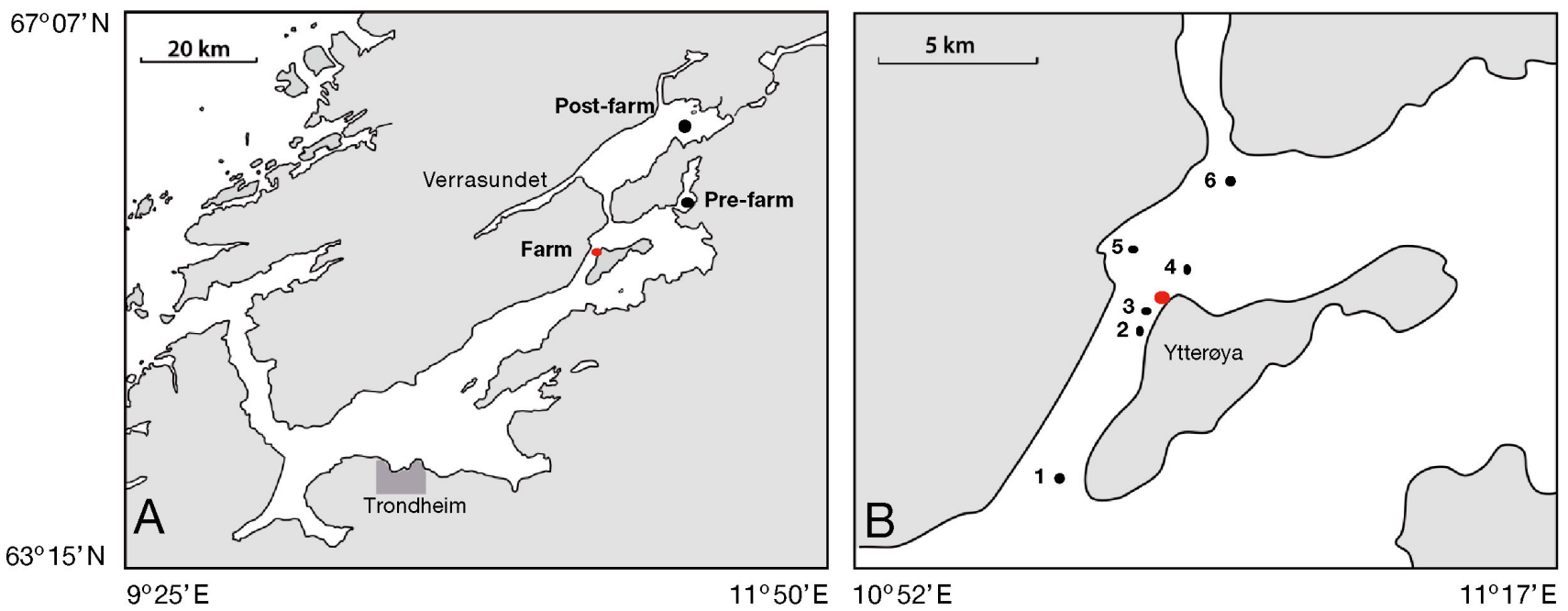

Fig. 1. (A) Locations of pre-farm (sampled in 2005 in Borgenfjorden) and post-farm (sampled in 2013 in Beitstadfjorden) sampling sites (black circles) in Trondheimsfjord. The location of the cod farm, near the island of Ytterøya, is indicated by a red circle. Verrasundet, in the innermost part of the fjord is the main wild cod spawning area in Trondheimsfjord. (B) Sampling areas of plankton net hauls for cod eggs (black circles). The downstream and upstream locations are indicated by numbers 1 and 6 , respectively; other hauls were taken in the vicinity of the cod farm. See Table 9 for exact coordinates of net hauls 


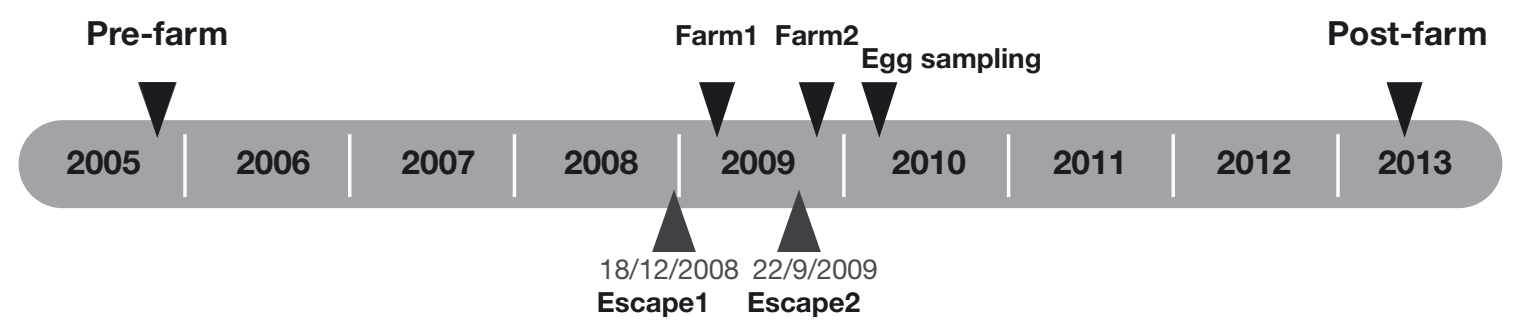

Fig. 2. Timeline of events in the study. Pre- and post-farming samples were taken several years prior to and after the period when the farm was operational (from December 2007 to April 2010). Escape1 was reported to consist of 25000 cod and Escape 2 of $42000 \mathrm{cod}$

shallow side-arm Borgenfjorden (Fig. 1A). Average age at maturity for the Trondheimsfjord cod is 4 yr (Ekli 1997) and the normal spawning season for the Trondheimsfjord cod is from March to May with a peak in April (Mork 1976, Sundnes 1980). A total of 895 wild and farmed cod individuals from the Trondheimsfjord were included in this study. Genetic and biological characteristics of wild cod before the presence of farming activity were based on the reference sample (hereafter called Pre-farm) (Table 1), which was caught with a bottom trawl operated from the NTNU research vessel Harry Borthen I in the Borgenfjord (Fig. 1A), a local spawning ground and nursery area for cod. Samples of farmed cod (Farm1 and Farm2) were taken after each of 2 major escape incidents (Fig. 2, Table 1). A post-farming reference sample of wild cod was taken $3 \mathrm{yr}$ after the termination of the cod farm (hereafter called Post-farm) (Table 1). Biological and genetic data as well as preserved tissues were available in the databases and collections at TBS (Kunz 2011). Farmed cod were obtained directly from the pens located near the Ytterøya Island in the inner Trondheimsfjord $\left(63^{\circ} 47^{\prime} 57.48^{\prime \prime} \mathrm{N}, 11^{\circ} 02^{\prime} 55.08^{\prime \prime} \mathrm{E}\right)$ (Fig. 1A). The supplier of cod eggs to the hatchery, Fosen Akvasenter (later renamed 'Atlantic cod juveniles'), confirmed that their brood stock consisted of cod taken from 5 different areas along the coast of Norway, not including the Trondheimsfjord. The eggs were from the first generation of selection (F1 generation) (T. Refstie pers. comm.). Fosen Akvasenter had supplied the farm with codlings (mean length $=\sim 13 \mathrm{~cm}$ ) in 2 batches: the first at the end of 2007 and the second in early 2008 (I. Tanem pers. comm.). Biological data and tissues samples were collected from both batches to establish a comprehensive genetic and biological signature of the farmed fish. The sampling was performed using the RV Gunnerus; the first cruise in March 2009 (Farm1) and the second in November 2009 (Farm2). In the simulated escape experiment, the tagging and release of a total of 400 farmed cod (Table 1) was executed from RV Gunnerus while moored to the net pens, and their individual postrelease behaviour was mapped from recapture reports managed by the Institute of Marine Research (IMR) in Bergen, Norway.

To evaluate the degree of 'escape by spawning' from the farm pens, plankton net hauls for cod eggs and larvae were conducted on locations in the vicinity of the farm at a time when the farm staff reported ongoing pen spawning. The Post-farm sample was collected in cylindrical pots $(60 \times 180 \mathrm{~cm}$, stretched mesh $2.5 \mathrm{~cm}$ ) at $10-20 \mathrm{~m}$ depths, $3 \mathrm{yr}$ after the commercial cod farm was closed down (Table 1).
Table 1. Sampling and DNA marker information for Atlantic cod Gadus morhua, including sample name (locations of samples shown in Fig. 1A), and sampling date. Total $(\mathrm{N})$ : total number of individuals genotyped, Bio $(\mathrm{N})$ : individuals with full biological data and tissue samples, Allo Loci: number of allozyme marker loci, DNA Loci: number of DNA marker loci, Tagged (N): number of individuals used in tagging experiment (only fin clips and length information available). nd = no data available

\begin{tabular}{|c|c|c|c|c|c|c|c|}
\hline Sample & Location & $\begin{array}{c}\text { Date } \\
\text { (dd/mm/yyyy) }\end{array}$ & $\begin{array}{l}\text { Total } \\
(\mathrm{N})\end{array}$ & $\begin{array}{l}\text { Bio } \\
(\mathrm{N})\end{array}$ & $\begin{array}{l}\text { Allo } \\
\text { Loci }\end{array}$ & $\begin{array}{l}\text { DNA } \\
\text { Loci }\end{array}$ & $\begin{array}{c}\text { Tagged } \\
(\mathrm{N})\end{array}$ \\
\hline Pre-farm & Borgenfjorden & 03/10/2005 & 192 & 192 & $4^{\mathrm{a}}$ & 10 & nd \\
\hline Farm1 & Ytterøya & $25 / 03 / 2009$ & 263 & $63^{a}$ & $4^{\mathrm{a}}$ & 10 & 200 \\
\hline Farm2 & Ytterøya & $02 / 11 / 2009$ & 248 & $48^{\mathrm{a}}$ & $4^{\mathrm{a}}$ & $10^{\mathrm{a}}$ & 200 \\
\hline Post-farm & Beitstadfjorden & 1 01/06/2013 & 192 & 192 & 4 & 10 & nd \\
\hline${ }^{\mathrm{a}}$ Data fron & Kunz (2011) & & & & & & \\
\hline
\end{tabular}

\section{Biological data}

Biological data included age, weight, total length, sex, and gonad maturation stage (Table 2). From tagged cod, only fin clips and total body length were collected. Age was determined by otolith reading according to Rollefsen (1933). The gonad maturation stage categories $(1=$ immature, $2=$ maturing, $3=$ running and $4=$ spent) followed Sivertsen (1935). 
Table 2. Biological sample information for Atlantic cod Gadus morhua including age (yr), mean weight (g), mean total length $(\mathrm{cm})$, and gonadic stage range (GS) according to Sivertsen (1935). nd: no data available

\begin{tabular}{|lccccc|}
\hline Sample & $\begin{array}{c}\text { Age } \\
(\mathrm{yr})\end{array}$ & $\begin{array}{c}\text { Weight } \\
(\mathrm{g})\end{array}$ & $\begin{array}{c}\text { Length } \\
(\mathrm{cm})\end{array}$ & GS & \% females \\
\hline Pre-farm & $2-4$ & 419 & 34.6 & $1-3$ & 48 \\
Farm1 & 2.5 & 1073 & 43.7 & $1-4$ & 35 \\
Farm2 & 2.2 & nd & 48.2 & $2-4$ & 40 \\
Post-farm & $\leq 2$ & 247 & 30.3 & 1 & 39 \\
\hline
\end{tabular}

\section{Tissue samples and genetic markers}

Informative tissue samples for known polymorphisms in cod (muscle, liver, and heart) were taken immediately after death and kept frozen at $-20^{\circ} \mathrm{C}$ during the cruises. For long-term storage, tissue samples were transferred to an ultra-low temperature freezer $\left(-70^{\circ} \mathrm{C}\right)$ at TBS after the cruise. Fin clips for DNA analyses were preserved in $96 \%$ ethanol and kept at room temperature. Methods for tissue sampling and storage, and tissue extract preparations using all tissue types, electrophoresis conditions, and allozyme genotyping followed Mork et al. (1983). Four allozyme loci were screened: lactate dehydrogenase $\left(L D H-3^{*}\right)$, phosphoglucose isomerase (PGI$\left.1^{*}\right)$, isocitrate dehydrogenase $\left(I D H P-1^{*}\right)$ and phosphoglucomutase $\left(P G M-1^{*}\right)$. The enzyme staining recipes followed the protocols of Aebersold et al. (1987). The microsatellite set analysed in this study included Gmo2 and Gmo132 (Brooker et al. 1994), Gmo3, Gmo8, Gmo19, Gmo34 and Gmo35 (Miller et al. 2000), Tch11 and Tch13 (O'Reilly et al. 2000). The nuclear RFLP locus Pan I (Pogson \& Fevolden 2003) was genotyped together with the microsatellites according to Stenvik et al. (2006).

\section{DNA extraction and amplification}

DNA isolation of the Farm2 sample was performed using the HotSHOT genomic DNA preparation method outlined in Truett et al. (2000). The remaining samples were isolated using Omega E-Z 96 Tissue DNA kit (Omega Bio-Tek). DNA was extracted from muscle tissues samples or fin clips from the tagged and released specimen. All microsatellites were labelled with fluorescent dye at the forward primer. The Pan I alleles were fluorescence-labelled according to Stenvik et al. (2006). The PCR was performed in a $2.5 \mu \mathrm{l}$ volume and comprised $1 \times$ Multiplex PCR kit (Qiagen) and 0.1-1.0 $\mu \mathrm{M}$ primer. The
PCR profile for both multiplexes consisted of an initial denaturation step at $95^{\circ} \mathrm{C}$ for $15 \mathrm{~min}$ followed by 22 cycles at $95^{\circ} \mathrm{C}$ for $30 \mathrm{~s}, 56^{\circ} \mathrm{C}$ for 3 min and $72^{\circ} \mathrm{C}$ for $1 \mathrm{~min}$. The PCR reaction was completed with a final elongation step at $60^{\circ} \mathrm{C}$ for $30 \mathrm{~min}$. Separation of the PCR products was conducted on a $3130 \mathrm{xl}$ Genetic Analyser (Applied Biosystems). The software Gene Mapper ${ }^{\circledR} 4.0$ (Applied Biosystems) was used for allele scoring and all alleles were visually inspected.

\section{Pen spawning}

The concentration of pen-spawned cod eggs in the vicinity of the farm was investigated by plankton net sampling on 18 February 2010. The sampling was designed to detect the general drift direction of the pelagic eggs relative to the location of the cod farm (Fig. 1B). The plankton net sampling (diameter = $100 \mathrm{~cm}$, mesh size $=1 \mathrm{~mm}$, surface hauls $=50 \mathrm{~m}$ ) was performed at 6 locations spanning the vicinity of the farm as well as locations upstream and downstream from the farm (Fig. 1B). The concentration of eggs refers to the number of eggs in each standardized haul. Cod eggs were identified by their visual appearance (translucent, visible embryonic cells, no oil drop) and size (diameter $=\sim 1.5 \mathrm{~mm}$ ) using a stereo microscope as described by Mork et al. (1983).

\section{Tagging and recapture experiment}

Two simulated farmed cod escape experiments were performed, each including 200 farmed cod ( 2.5 yr old) (Table 2) which were tagged and released from alongside the farm pens in March and November 2009 (Table 1). Both Lea hydrostatic tags $(\mathrm{n}=100)$ and Dart tags $(\mathrm{n}=300)$ were attached in front of the first dorsal fin. Tagging procedures were approved by the Norwegian Animal Research Authority. Recaptures were performed mostly by the public; tag reporters received a small compensation when tags carrying information of the recapture site were returned to the IMR.

\section{Statistical analyses}

MICRO-CHECKER was used to test the microsatellite loci for null alleles and stuttering (Van Oosterhout et al. 2004). The number of alleles, observed and expected heterozygosity, unbiased Nei's genetic distance, and the fixation index $\left(F_{\mathrm{ST}}\right)$ were calculated 
using GenAlEx (Peakall \& Smouse 2006, 2012). Candidate loci for positive, neutral and balancing selection under the infinite allele mutation model were detected by the $F_{\mathrm{ST}}$-outlier detection method implemented in LOSITAN (Antao et al. 2008). Using default parameters, outlier analyses were also redone after removing detected outlier loci ('Neutral' mean $F_{\mathrm{ST}}$ and 'Force mean' $F_{\mathrm{ST}}$ option). The R package HIERFSTAT (Goudet 2005) was used to estimate allelic richness; defined as the rarefied allelic count per locus and population. The significance of the differences in allelic richness was tested using KruskalWallis ANOVA, where the mean allelic richness over all loci was tested between all samples (Kruskal \& Wallis 1952, McDonald 2009). Exact tests for HardyWeinberg (HW) equilibrium, linkage disequilibrium (LD), and exact G-tests for genic differentiation were performed using the web version of Genepop 4.2 (Raymond \& Rousset 1995, Rousset 2008). All analyses were executed with the default Markov chain parameters and overall p-values were calculated by Fisher's method. Bonferroni procedures were used to correct for multiple tests (Rice 1989). Reducing the degrees of freedom (df) in Rows by Columns $(\mathrm{R} \times \mathrm{C})$ chi-square tests, by pooling all the alleles except the most common allele, provided a higher test power (Wright 1978). The frequency of the overall most common allele in the samples (all others pooled) were used to investigate possible concealing effects, such as the Post-farm wild cod sample potentially having been affected by 2 escaped batches (Farm1 and Farm2) with different allele frequencies. This procedure was executed for all markers. MEGA ver. 6 was used to construct the unweighted paired-group method with arithmetic mean (UPGMA) dendrograms (Tamura et al. 2013). Bootstrap replications $(n=10000)$ were executed in POPTREEW to compute the probability of confidence of the UPGMA dendrograms (Takezaki et al. 2014). Because of difference in level of polymorphism, which leads to different power in statistical tests and interpretation of $F_{\mathrm{ST}}$, the allozymes and microsatellites were analysed separately (Estoup et al. 1998). STRUCTURE 2.3.4, a Bayesian, Markov chain Monte Carlo (MCMC) program was used to cluster individuals based on estimated levels of individual admixture (Pritchard et al. 2000, Hubisz et al. 2009). An admixture model (MCMC 100000 iterations, 200000 burn in, 10 iterations, $k=1-5$ ) analyses were completed using DNA loci only, both 10 loci and a reduced set of 7 loci. The number of populations $(k)$ that best describes the data material was determined using STRUCTURE Harvester (Evanno et al. 2005).

\section{Statistical power}

The power of the marker set to detect genetic differentiation was estimated using POWSIM 4.1 (Ryman \& Palm 2006). An effective population size $\left(\mathrm{N}_{\mathrm{E}}\right)$ of 5000 and generations of drift ranging 0-15 were used in the set up. Simulations were run 10000 times for each number of generations of drift. To find a value of $F_{\text {ST }}$ corresponding to 50, 80 and $95 \%$ probability of detection, a linear regression between the nearest simulated points were used. The POWSIM simulations were used for the full marker set including allozyme and DNA loci, and a DNA marker set which excluded Tch11, Gmo132 and Pan I. To test the power on the dataset used, Post-farm sample genotypes were replaced with 5, 7, 10, and $20 \%$ Farm 1 and Farm2 genotypes, respectively. Pairwise $F_{\mathrm{ST}}$, with probability of being significantly different to zero based on 999 permutations, were calculated for each pair of Pre-farm and 'replaced' Post-farm samples using the AMOVA function in GenAlEx (Peakall \& Smouse 2006, 2012).

\section{RESULTS}

The wild cod specimens in the Pre-farm group were 2-4 yr old, while those in both of the farmed batches were a little more than 2 yr old (Table 2). The Postfarm sample consisted of juveniles of $2 \mathrm{yr}$ or younger, thus born $3 \mathrm{yr}$ after the termination of the farm (Table 2). The majority of the Farm1 individuals, which were sampled in March 2009, had running gonads (stage 3) (Table 2). Farm2, which was sampled in November 2009, consisted mostly of cod with maturing or spent gonads (i.e. in stages 2 and 4) (Fig. 3).

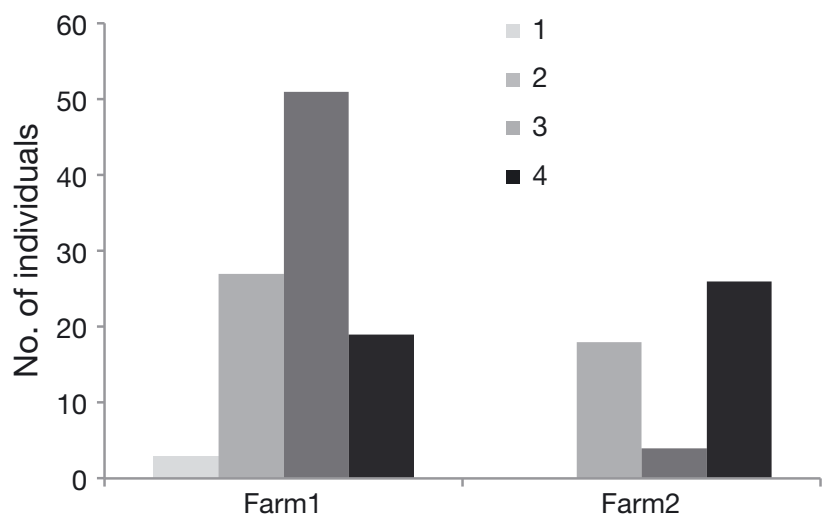

Fig. 3. Gonadic maturation stages $(1=$ immature, $2=$ maturing, 3 = running and $4=$ spent) in farmed Atlantic cod samples (mean age $=2.4 \mathrm{yr}$ ). Both samples were taken in 2009; Farm1 in March and Farm2 in November 
Based on weight information provided by the farm company, the 2008 escape was from the Farm1 batch and the 2009 escape from Farm2 batch.

\section{Statistical analyses}

Altogether 13 and 221 alleles were detected for the allozymes and microsatellites, respectively, in the Pre-farm, Farm1, Farm2, and Post-farm samples. The scoring success was $96-100 \%$ for allozyme loci and 94-96\% for DNA marker loci.

\section{Allozyme markers}

All 4 allozyme loci were in HW equilibrium in all farmed and wild cod samples (Table 3); individual locus results are given in Table S1 in the Supplement at www.int-res.com/articles/suppl/q007p253_ supp.pdf. No significant LD was detected for any pair of loci in any sample (Table S1). The allele frequencies at the 4 loci in the 2 farmed samples were not significantly different from each other (see Bonferroni adjusted exact G-tests p-values in Table 4). However, the allele frequencies in the Farm1 sample differed significantly from the Prefarm sample, and the Post-farm sample differed significantly from the Farm2 but not from the Pre-farm or the Farm1 (Table 4). Heterozygosities did not differ significantly between farmed and wild cod (Table S1). Several measures of genetic diversity showed no significant differences between the 4 groups (Kruskal-Wallis test; $\mathrm{p}=0.69$ ) (Table 3 ). Chi-squared $\mathrm{R} \times \mathrm{C}$ contingency table tests of allele frequencies (i.e. testing for the most common allele and pooled remaining alleles) in the allozyme loci of Pre-farm and Post-farm samples revealed no significant $p$-value at any locus (Table 5). The largest unbiased Nei's genetic distance $(D=0.017)$ was between the 2 farmed samples (Table 6).
Table 4. p-values from pairwise exact G-tests of genic differentiation across all loci and Atlantic cod samples (Fisher's method). Significant $p$-values after Bonferroni correction are shown in bold (adjusted p-value $=0.009$ ). Above diagonal: microsatellites excluding Gmo132, Tch11 and Pan I. Below diagonal: allozymes

\begin{tabular}{|lrrrr|}
\hline & Pre-farm & Farm1 & Farm2 & Post-farm \\
\hline Pre-farm & & $<\mathbf{0 . 0 0 1}$ & $\mathbf{< 0 . 0 0 1}$ & 0.578 \\
Farm1 & $\mathbf{0 . 0 0 1}$ & & $\mathbf{0 . 0 0 1}$ & $\mathbf{< 0 . 0 0 1}$ \\
Farm2 & 0.438 & 0.009 & & $<\mathbf{0 . 0 0 1}$ \\
Post-farm & 0.345 & $\mathbf{0 . 0 0 1}$ & $\mathbf{< . 0 0 2}$ & \\
\hline
\end{tabular}

\section{DNA markers}

Tests for the reliability of the different DNA markers were carried out prior to the main data analyses. Significant evidence of the presence of null alleles was found in the Pre-farm and Farm1 samples at Gmo2 and Tch11, respectively. The Post-farm sample showed evidence of null allele presence at 3 loci: Gmo2, Gmo19 and Tch11. Tests for positive selection fell out significant only for Gmo132; this result was consistent using either the 'Neutral mean $F_{\mathrm{ST}}$ ' or 'Force mean $F_{\mathrm{ST}}$ ' option in LOSITAN. Pooled results from all markers in each sample revealed several significant (after Bonferroni correction) deviations from HardyWeinberg genotype composition $\left(F_{\text {IS }}\right)$ (Table 7$)$. In the Pre-farm sample, the significant deviation was caused by the locus Tch11 (Table S2 in the Supplement). Adjustments for the presence of null alleles did not remove the significance. The Post-farm sample showed significant deviation from HW equilibrium at Gmo8 (Table S2). Farm1 had 4 and Farm2 had 6 loci in HW disequilibrium (Bonferroni adjusted p-values $=0.0003$ ) (Table S2). The Pre-farm sample showed LD ( $<$ < 0.0001 ) for 2 pairs of loci; Gmo8/Gmo19 and Gmo8/Tch13. The Post-farm sample showed no significant LD. Nine and 11 pairs showed significant LD in Farm1 and Farm2, respectively ( $p<0.0001)$.

Table 3. Genetic characterization of Atlantic cod samples by allozyme loci. N: number of allozyme-genotyped individuals, $H_{\text {obs }}$ : observed heterozygosity, $H_{\text {exp }}$ : expected heterozygosity, $F_{\mathrm{IS}}$ : Wright's $F_{\mathrm{IS}}$ value, $N_{\mathrm{A}}$ : number of alleles, $N_{\mathrm{PA}}$ : number of private alleles, $A R$ : allelic richness. Mean values are given $\pm \mathrm{SE}$

\begin{tabular}{|lcccrrrr|}
\hline Sample & $\mathrm{N}$ & $H_{\mathrm{obs}}$ & $H_{\exp }$ & \multicolumn{1}{c}{$F_{\mathrm{IS}}$} & \multicolumn{1}{c}{$N_{\mathrm{A}}$} & $N_{\mathrm{PA}}$ & \multicolumn{1}{c|}{$A R$} \\
\hline Pre-farm & 192 & $0.305 \pm 0.10$ & $0.305 \pm 0.10$ & -0.009 & $2.75 \pm 0.48$ & $0.25 \pm 0.25$ & $2.38 \pm 0.32$ \\
Farm1 & 63 & $0.323 \pm 0.12$ & $0.325 \pm 0.11$ & 0.032 & $1.75 \pm 0.25$ & $0.00 \pm 0.00$ & $1.75 \pm 0.25$ \\
Farm2 & 48 & $0.336 \pm 0.12$ & $0.311 \pm 0.10$ & -0.046 & $2.25 \pm 0.25$ & $0.25 \pm 0.25$ & $2.22 \pm 0.22$ \\
Post-farm & 192 & $0.320 \pm 0.09$ & $0.318 \pm 0.09$ & 0.032 & $2.75 \pm 0.48$ & $0.25 \pm 0.25$ & $2.45 \pm 0.29$ \\
\hline
\end{tabular}


Table 5. Frequency of the most common allele (100) at allozyme loci in the Atlantic cod samples. A potential concealing effect was possible at all loci since the 2 farmed samples displayed higher and lower frequency values than the Prefarm sample. 'Direction of Post-farm to Farm' denotes whether the allele frequency in the Post-farm sample is as expected if caused by farmed cod. 'Pre vs. Post $\chi^{2}$ p-value' denote $p$-value for Chi-square test between Pre-Farm and Postfarm samples using the most common allele and pooled remaining alleles. $\mathrm{N}$ : number of allozyme-genotyped individuals

\begin{tabular}{|lccccc|}
\hline Sample & $\mathrm{N}$ & LDH-3 & IDH-1 & PGM-1 & PGI-1 \\
\hline Pre-farm & 192 & 0.635 & 0.844 & 0.984 & 0.685 \\
Farm1 & 63 & 0.500 & 0.713 & 1.000 & 0.733 \\
Farm2 & 48 & 0.628 & 0.865 & 0.969 & 0.594 \\
Post-farm & 192 & 0.591 & 0.828 & 0.964 & 0.716 \\
Direction of Post-farm to Farm & & Farm1 & Farm1 & Farm2 & Farm1 \\
Pre- vs. Post-farm $\chi^{2}$ p-value & & 0.208 & 0.559 & 0.070 & 0.344 \\
\end{tabular}

Of these, 2 pairs occurred in both samples: Gmo19/ Gmo2 and Gmo8/Gmo2 (Table S2). Mean allelic richness was nominally but not significantly lower in the 2 farm samples compared to the wild cod (Table 7). Among all DNA marker loci there were no significant differences in allelic richness among the samples (Kruskal-Wallis test; adjusted $H=3.0$, df $=3, \mathrm{p}=$ 0.392). Observed heterozygosities showed similar values in wild and farmed cod (Kruskal-Wallis test for homogeneity of mean heterozygozity for all loci among all samples; adjusted $H=3.0, \mathrm{df}=3, \mathrm{p}=0.396$, Table 7). The difference in the number of private alleles over all loci and all 4 samples was not significant (Kruskal-Wallis test; adjusted $H=2.4$, df =3, $\mathrm{p}=0.497$ ).

Table 6. Nei's unbiased genetic distances between Atlantic cod samples for allozyme and DNA markers. Column values (above diagonal): DNA markers excluding Gmo132, Tch11 and Pan I. Row values (below diagonal): allozymes

\begin{tabular}{|lcccc|}
\hline & Pre-farm & Farm1 & Farm2 & Post-farm \\
\hline Pre-farm & & 0.055 & 0.048 & 0.000 \\
Farm1 & 0.011 & & 0.048 & 0.051 \\
Farm2 & 0.002 & 0.017 & & 0.046 \\
Post-farm & 0.000 & 0.006 & 0.005 & \\
\hline
\end{tabular}

\section{Allele frequency relationships among samples}

The 2 farmed cod samples differed in allele frequencies at several DNA marker loci. Only 2 loci (Gmo35 and Pan I) were in opposite directions relative to the corresponding values in the Pre-farm sample, potentially creating a concealing effect at these 2 loci in an introgression situation (Table 8). Both Farm1 and Farm2 differed significantly from Pre-farm and Post-farm ( $p<0.001$ ) in all tests. Using the full marker set in an exact G-test for genic differentiation, the Pre-farm and Post-farm samples showed significant differences $(\mathrm{p}<0.002)$; however the significance was caused by Tch11 and Pan I. p-values changed following the exclusion of Pan I ( $p=0.042)$, and after exclusion of Tch11 $(\mathrm{p}=0.043)$. Excluding both Tch11 and Pan I resulted in no significant allele frequency differences between Pre-farm and Postfarm ( $p=0.578$ ) (Table 4). Noteworthy, the change between Pre-farm and Post-farm frequency of the most common allele at Tch11 was in the opposite direction of what would be expected if caused by a farm fish introgression. The allele frequencies at the DNA loci in the 4 samples were subjected to UPGMA cluster analysis and dendrogram construction using Nei's unbiased genetic distance (Table 6). The topography of the dendrogram from allozymes and the reduced DNA marker set were basically similar and confirmed graphically the genetic relationships among the 4 samples (Fig. 4).

For the markers which were not affected by a potential concealing effect, the frequency of the most common allele in the Post-farm sample changed towards the farmed cod at 5 of 8 loci, of these only Gmo132 was significant (pooling of alleles, chi-square test $p$-value $=0.004)$ (Table 8$)$. For the 2 markers for

Table 7. DNA marker characteristics for all 10 loci. $\mathrm{N}=$ number of genotyped Atlantic cod individuals, $H_{\mathrm{obs}}$ : observed heterozygosity, $H_{\text {exp }}$ : expected heterozygosity, $F_{\mathrm{IS}}$ : Wright's $F_{\mathrm{IS}}$ values (all samples were significantly different from HW equilibrium; exact HW conformance test $\mathrm{p}<0.001$ for all samples), $N_{\mathrm{A}}$ : number of alleles, $N_{\mathrm{PA}}$ : number of private alleles, $A R$ : allelic richnes. Mean values are given $\pm \mathrm{SE}$

\begin{tabular}{|lcccccrc|}
\hline Sample & $\mathrm{N}$ & $H_{\mathrm{obs}}$ & $H_{\text {exp }}$ & $F_{\mathrm{IS}}$ & $N_{\mathrm{A}}$ & $N_{\mathrm{PA}}$ & $A R$ \\
\hline Pre-farm & 192 & $0.684 \pm 0.087$ & $0.708 \pm 0.092$ & 0.022 & $18.3 \pm 3.7$ & $1.8 \pm 0.6$ & $15.8 \pm 2.9$ \\
Farm1 & 96 & $0.683 \pm 0.095$ & $0.683 \pm 0.092$ & 0.008 & $10.9 \pm 1.9$ & $0.6 \pm 0.3$ & $10.9 \pm 1.8$ \\
Farm2 & 192 & $0.634 \pm 0.101$ & $0.680 \pm 0.106$ & 0.077 & $15.2 \pm 3.0$ & $1.5 \pm 0.5$ & $14.0 \pm 2.6$ \\
Post-farm & 192 & $0.663 \pm 0.093$ & $0.702 \pm 0.102$ & 0.041 & $17.3 \pm 3.2$ & $1.0 \pm 0.3$ & $15.2 \pm 2.6$ \\
\hline
\end{tabular}


Table 8. Number of genotyped Atlantic cod individuals, and frequency of the most common allele at DNA marker loci in the samples. 'Potential concealing effect' is the possibility of a concealing effect when the 2 farmed samples display both higher and lower frequency values than Pre-farm ( $\mathrm{Y}=$ yes, $\mathrm{N}=$ no). 'Direction Post-farm to Farm' denotes whether the allele frequency in the Post sample is as expected if caused by farmed cod. 'Pre vs. Post-farm $\chi^{2} p$-value' denote $p$-value from Chi-square test for pooled alternative alleles at each marker for Pre-farm vs. Post-farm samples. Significant $\mathrm{p}$-values after Bonferroni correction are shown in bold (adjusted p-value $=0.005$ )

\begin{tabular}{|lccccccccccc}
\hline Sample & N & Gmo2 & Gmo3 & Gmo8 & Gmo19 & Gmo34 & Gmo35 & Gmo132 & Tch11 \\
& Allele: & & 107 & 191 & 124 & 145 & 98 & $\begin{array}{c}\text { Tch13 } \\
126\end{array}$ & $\begin{array}{c}\text { Pan I } \\
\text { A }\end{array}$ \\
\hline Pre-farm & 192 & 0.251 & 0.862 & 0.226 & 0.143 & 0.609 & 0.270 & 0.471 & 0.124 & 0.185 & 0.929 \\
Farm1 & 96 & 0.234 & 0.898 & 0.122 & 0.214 & 0.747 & 0.298 & 0.188 & 0.070 & 0.126 & 0.875 \\
Farm2 & 192 & 0.242 & 0.916 & 0.217 & 0.296 & 0.628 & 0.265 & 0.136 & 0.086 & 0.120 & 1.000 \\
Post-farm & 192 & 0.240 & 0.886 & 0.201 & 0.147 & 0.587 & 0.243 & 0.403 & 0.135 & 0.189 & 0.981 \\
Potential concealing effect & & $\mathrm{N}$ & $\mathrm{N}$ & $\mathrm{N}$ & $\mathrm{N}$ & $\mathrm{N}$ & $\mathrm{Y}$ & $\mathrm{N}$ & $\mathrm{N}$ & $\mathrm{N}$ & $\mathrm{Y}$ \\
Direction Post-farm to Farm & & $\mathrm{Y}$ & $\mathrm{Y}$ & $\mathrm{Y}$ & $\mathrm{Y}$ & $\mathrm{N}$ & Farm2 & $\mathrm{Y}$ & $\mathrm{N}$ & $\mathrm{N}$ & Farm2 \\
Pre- vs. Post-farm $\chi^{2}$ p-value & & 0.288 & 0.078 & 0.156 & 0.573 & 0.308 & 0.198 & $\mathbf{0 . 0 0 4}$ & $<\mathbf{0 . 0 0 1}$ & 0.512 & $<\mathbf{0 . 0 0 1}$ \\
& & & & & & & & & & & \\
\hline
\end{tabular}

which a concealing effect could not be ruled out (Gmo35 and Pan I), the frequency of the most common allele in the Post-farm sample indicated that Farm2 potentially might have had the strongest impact, though only Pan I was statistically significant (Table 8). STRUCTURE Harvester suggested that $k=$ 2 best described the dataset. The individual admixture analyses in STRUCTURE clustered mainly the Pre-farm and Post-farm individuals together, and the farmed samples in the other cluster for both the full DNA marker set and the reduced set (Figs. S1 \& S2 in the Supplement). There was evident similarity in the clustering proportions of Pre-farm and Post-farm (Table S3).

\section{Statistical power of the marker sets}

POWSIM showed that the total marker set containing 4 allozymes, 9 microsatellites and 1 RLPF had an $80 \%$ probability to detect differentiation at $F_{\mathrm{ST}}=$

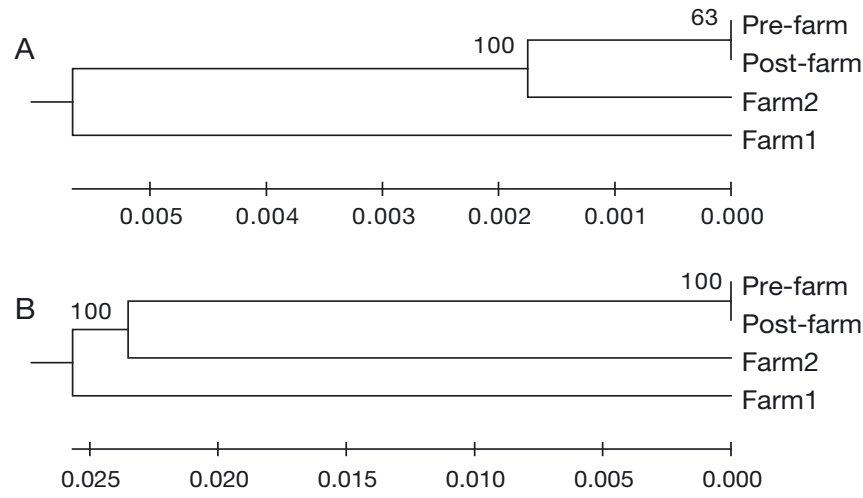

Fig. 4. UPGMA dendrograms based on Nei's unbiased genetic distances between the 4 Atlantic cod samples for (A) allozymes (sum of branch length $=0.0131$ ), and (B) DNA markers excluding Gmo132, Tch11 and Pan I (sum of branch length $=0.0748)$. Bootstrap value $(\%)$ shown at node
0.0010. For $F_{\mathrm{ST}}=0.0015$, the probability was $95 \%$. After assessing the reliability of the markers, the reduced DNA loci set on which we based our conclusions had a similar power of detecting differentiation with an $80 \%$ probability at $F_{\mathrm{ST}}=0.0009$ and $95 \%$ probability at $F_{\mathrm{ST}}=0.0014$. The marker set showed a $95 \%$ probability of detection for a simulated introgression of $10 \%$ farmed genotypes, and a $50 \%$ probability of detection for a $5 \%$ simulated farmed introgression (Fig. 5, Table S4 in the Supplement).

\section{Pen spawning}

Pelagic cod eggs in early development stages were found in plankton net samples taken at various dis-

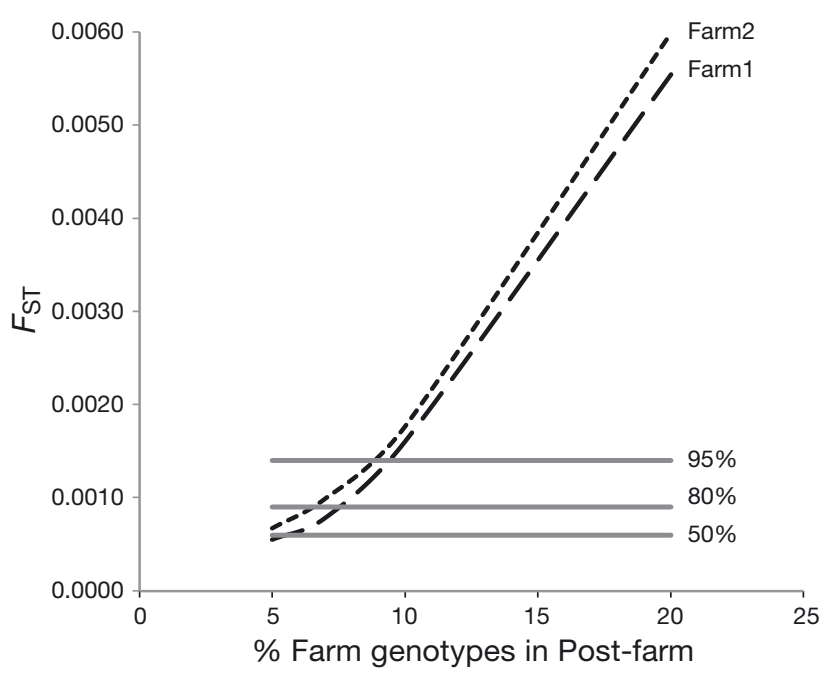

Fig. 5. Fixation index $\left(F_{\mathrm{ST}}\right)$ values from pairwise tests of Prefarm and Post-farm Atlantic cod samples, where Post-farm individuals have been replaced by 5, 7, 10, and $20 \%$ Farm 1 and Farm 2 individuals, respectively. Levels of probability detection at $95 \%, 80 \%$ and $50 \%$ are drawn at $F_{\mathrm{ST}}$ levels $0.0014,0.0009$ and 0.0006 , respectively 
Table 9. Number of pelagic Atlantic cod Gadus morhua eggs in vertical plankton net hauls (1 mm mesh, 50-0 m depth) at various positions downstream, in the vicinity of, and upstream of the cod farm at Ytterøya in the Trondheimsfjord. Geographical coordinates for 6 separate plankton net hauls are given. Characterization is the location of the plankton net sampling site relative to the cod farm and in lieu of the estuarine current direction in the fjord

\begin{tabular}{|lccl|}
\hline $\begin{array}{l}\text { Location } \\
\text { no. }\end{array}$ & Position & $\begin{array}{c}\text { No. of } \\
\text { cod eggs }\end{array}$ & $\begin{array}{l}\text { Characteri- } \\
\text { zation }\end{array}$ \\
\hline 1 & $63^{\circ} 44^{\prime} 50.30^{\prime \prime} \mathrm{N}, \quad 10^{\circ} 58^{\prime} 59.43^{\prime \prime} \mathrm{E}$ & 75 & $\begin{array}{l}\text { Downstream } \\
\text { Vicinity }\end{array}$ \\
2 & $63^{\circ} 47^{\prime} 57.54^{\prime \prime} \mathrm{N}, 1^{\circ} 02^{\prime} 26.28^{\prime \prime} \mathrm{E}$ & 14 & Vicinity \\
3 & $63^{\circ} 48^{\prime} 12.06^{\prime \prime} \mathrm{N}, 1^{\circ} 02^{\prime} 48.30^{\prime \prime} \mathrm{E}$ & 42 & Vicinity \\
4 & $63^{\circ} 48^{\prime} 24.00^{\prime \prime} \mathrm{N}, 11^{\circ} 03^{\prime} 13.80^{\prime \prime} \mathrm{E}$ & 15 & Vicinity \\
5 & $63^{\circ} 48^{\prime} 31.86^{\prime \prime} \mathrm{N}, 11^{\circ} 02^{\prime} 04.50^{\prime \prime} \mathrm{E}$ & 8 & Upstream \\
6 & $63^{\circ} 49^{\prime} 35.16^{\prime \prime} \mathrm{N}, 11^{\circ} 05^{\prime} 01.08^{\prime \prime} \mathrm{E}$ & 2 & \\
\hline
\end{tabular}

cipient are all examples of such scenarios. Additionally, the severity of the introgression is of crucial importance (Baskett et al. 2013). The situation in the Trondheimsfjord in this study was relatively simple in these respects, since the potential donor source was temporal, transient and well characterized, and there was no previous farming history. This study benefitted also from the extensive time series on the biological and genetic characteristics of the local cod stock in the Trondheimsfjord. The 2 batches of farmed cod showed significant genetic differences between each other as well as to the wild population. Such genetic heterogeneity pres-

tances from the farm pens on 18 February 2010. The concentration of eggs was higher in the vicinity and downstream of the farm pens than upstream (Table 9). At the time of sampling, extensive net spawning was occurring as noted by the farm staff and by gonad inspections on cod taken from the pen (Fig. 3). The early development stages of the eggs in the plankton net samples confirmed a recent and hence off-season spawning.

\section{Recaptures from simulated escape experiments}

A total of 17 recaptures were taken between 11 and 191 days after release, which corresponds to a $4 \%$ recapture rate. Recaptures occurred throughout the Trondheimsfjord, both upstream and downstream of, but mostly in the vicinity of the release site. Average distance of the recapture site was $20 \mathrm{~km}$, and the maximum distance was $70 \mathrm{~km}$ coastwards from the release site.

\section{DISCUSSION}

The present panel of assumingly reliable allozyme and DNA markers did not detect any genetic change in the local population post cod-farming activity. The statistical power of this marker set, used to detect genetic differences with a significant biological meaning (Ryman et al. 2006, Waples 1998), was estimated by POWSIM to be high. Certain scenarios of genetic introgression are particularly difficult to analyse (Glover et al. 2011); small genetic differences between the donor and the recipient, multiple donor sources, and multiple introgression events in the re- ent within a farmed cod source was also reported by Glover et al. (2010). The farmed cod microsatellite loci showed multiple cases of LD, and most loci were not in HW equilibrium (Table S2). Such observations are not unexpected in domestic cod populations, where small effective population sizes, non-random matings, and continuous sorting by size are common (Glover 2010).

\section{Assessment of the allozyme markers}

Mork \& Sundnes (1985) reported a higher survival in juvenile cod for double heterozygotes of LHD and PGI, which they suggested was evidence of selection, possibly in form of heterosis which at equilibrium will stabilize allele frequencies. In the present material there were no over-representation of double heterozygotes or other LD, and we considered the allozyme loci to be reliable in that respect. No genetic differentiation was found between Pre-farm and Post-farm samples at any allozyme locus. The genetic distances between the farmed samples were larger than between the farmed and wild cod groups (Table 6). Historically, allozyme markers have shown low differentiation over the entire species range of Atlantic cod (Mork et al. 1985). The potential presence of any concealing effect of the allozyme loci supported the decision to perform separate statistical analyses of allozymes and DNA loci.

\section{Assessment of microsatellites and Pan I}

The DNA type genetic markers in this study have been widely used in studies of cod population genetic 
structure (Fevolden \& Pogson 1997, Knutsen et al. 2003, Skarstein et al. 2007, Westgaard \& Fevolden 2007, Wennevik et al. 2008, reviewed in Nordeide et al. 2011), as well as in studies on genetic aspects of cod farming (Delghandi et al. 2003, Dahle et al. 2006, Fevolden et al. 2009, Glover et al. 2010, 2011). There is published evidence for selection at Gmo34 (Westgaard \& Fevolden 2007), but the material in this study did not signal selection effects at this locus, which also is not represented in the locus panel for the aforementioned Trondheimsfjord time series (see 'Introduction'). Pan I was included in the present study because it was a potentially efficient marker (Glover et al. 2010) if the brood stock of the farmed cod contained sufficient representatives from the Northeast Arctic cod. The Northeast Arctic cod stock is known to have Pan I allele frequencies very different from Norwegian coastal cod (NCC), including the Trondheimsfjord cod (Karlsson \& Mork 2003, 2005, Sarvas \& Fevolden 2005, Westgaard \& Fevolden 2007, Wennevik et al. 2008). However, the farmed cod in this study turned out to have Pan I allele frequencies similar to NCC, which reduced its potential as a key marker for introgression. For the Gmo132 and Pan I DNA markers, the local Trondheimsfjord cod has shown selection effects in the form of significant HW imbalance as well as temporal instability and sex differences in allele frequencies based on the time series for the Trondheimsfjord cod (Karlsson \& Mork 2003, 2005). Both Gmo132 and Pan I showed significant allele frequency differences between Prefarm and Post-farm samples when pooling alleles and employing a chi-square test. However, the observed allele frequency differences for Gmo132 and Pan I are actually within the range of their natural temporal fluctuations in the Trondheimsfjord as reported by Karlsson \& Mork (2003, 2005). It is generally accepted that Gmo132 and Pan I are under selection in Atlantic cod (reviewed in Nordeide et al. 2011). In analyses of sample heterogeneity based on the full DNA loci set (exact G-tests), the prominent sources of significant allele frequency differences between Pre-farm and Post-farm samples were Tch11 and Pan I. Tch11 showed significant presence of null alleles and deviated strongly from HW equilibrium in the Pre-farm sample, signaling its unsuitability in the present analyses of introgression (Waples 2015). Also, the frequency of the most common allele for Tch11 was higher in Post-farm than Pre-farm, in contrast to the 2 farmed samples, which both had a lower frequency of this allele than the Pre-farm wild sample (Table 8). This implies that the contribution to differentiation at Tch11 could not be due to an impact from farmed cod. Furthermore, Dahle et al. (2006) reported particularly high differentiation and null alleles in Tch11 (Dahle et al. 2006), and Glover et al. (2010) reported a high gene diversity and $F_{\mathrm{ST}}$ value for Tch11, Although many other studies employing Tch11 have not reported unusual characteristics of this marker (O'Reilly et al. 2000, Delghandi et al. 2003, Nielsen et al. 2006, Poulsen et al. 2006, Wesmajervi et al. 2006, Westgaard \& Fevolden 2007, Wennevik et al. 2008, Nielsen et al. 2009, Glover et al. 2011). In this study, the very directions of the nominal Pre- to Post-farm allele frequency changes at Tch11 and Pan I as potential effects of introgression from Farm1 and Farm2 gene pools were contradictory and did not tell a consistent story (Table 8). This evidence suggested that more reliable conclusions were obtained from analyses which left out these 2 DNA loci from the genetic marker set (cf. Larsson et al. 2007, Eiríksson \& Árnason 2013).

\section{Apparent lack of genetic contribution from pen spawning to the wild stock}

The date of pelagic egg sampling (18 February) was before the natural spawning period, during MarchMay, of the wild cod and most other gadoids in the Trondheimsfjord (Sundnes 1980). Thus, no wild cod eggs were expected in the plankton net samples on that date. Furthermore, there are no known natural spawning sites for cod in the close vicinity of the cod farm location. At the time of sampling, extensive net spawning was occurring as noted by the farm staff and by gonad inspections of cod samples taken from the pen. The only other gadoid eggs in the fjord which might be found in February are those from the early spawner saithe, Pollachius virens, which have eggs that are easily distinguished from cod eggs by their much smaller, non-overlapping diameter (Mork et al. 1983). Estuarine circulation in the Trondheimsfjord is known to create a relatively strong net outgoing (coastward) current through the Nordviksund passage, where the cod farm was located (Jacobson 1983). The tidal movement and temporal local eddies might affect the course of pelagic egg drift from the pens to some extent. However, the expected net effect of these drivers in this part of the Trondheimsfjord is an outgoing transport of pelagic eggs in the upper water layers, where the newly spawned cod eggs reside. The results from the planktonic egg survey supported this expectation, in that the abundance of cod eggs was higher close to the net pens than farther off, and much higher downstream than upstream from the cod 
farm (Table 9). Assuming a passive pelagic drift of the net-pen spawning products (i.e. eggs, larvae and later on codlings) during a 5 mo long pelagic stage, offspring spawned in the mid-part of the Trondheimsfjord, where the cod farm was located, may be transported out of the fjord before settling on the bottom. The extent to which this occurs has been shown to vary annually, depending on the strength of the annual spring flood in the fjord (Dahl 1899, Swenander 1906). A significant negative correlation between the magnitude of the spring flood and the year-class strength of cod in the Trondheimsfjord was reported by Ekli (1997). Together, these factors would indicate that farm-spawned eggs and later, larvae, may eventually be carried out of the fjord by the outgoing estuarine currents during their pelagic stage. To the degree that such transport takes place, it would tend to reduce, but not exclude the possibility of a genetic introgression in the local cod stock by net-spawning. Uglem et al. (2012) simulated egg dispersal for a $46 \mathrm{~d}$ period after spawning for this cod farm and fjord system, and indicated that the probability of eggs being carried out of the fjord by the estuarine circulation was 60 times higher for eggs spawned from the fish farm compared to those spawned from the main wild cod spawning site located further inwards in the fjord. During the entire pelagic period (eggs, larvae and pelagic codlings) until settling, and which in this study also includes the time of the annual spring flood, the probability of drifting out of the fjord is likely to be higher. The survival of cod larvae from pen spawning would depend on the presence of suitable food items (normally live nauplii larvae of crustaceans) in high concentrations within 1-2 d after hatching. The 'match-mismatch' model of fish larvae survival (Cushing 1990) implies that the annual spawning event of wild cod populations must be tuned to the annual plankton blooms in the fjord; otherwise, the larvae would starve and die. The present data on the pen spawning in the Ytterøya Farm show that large parts of the pen spawning occurred before the commencement of the annual spring plankton bloom and the wild cod spawning period in the fjord, and that the available planktonic prey at that point in time might be critically scarce. This would negatively affect the survival of the pen-spawned larvae. Reports also exist of a generally lower hatching success in fertilized eggs of farmed cod than wild cod (Salze et al. 2005, Puckrin et al. 2013). In the present pen spawning, the egg quality was unknown; however, a lower egg quality would have contributed to the lack of a detectable genetic impact of farmed cod net-spawning on the wild cod stock in this fjord system.

\section{Dispersal of escaped farmed cod}

The tagging experiment, simulating an escape of cod from the farm pens, showed a rapid geographical dispersal of tagged cod and relatively few recaptures, which all were taken within a limited period of time ( $6 \mathrm{mo})$. The geographical pattern of recaptures indicated a non-directional diffusion of the released farmed cod throughout most parts of the Trondheimsfjord. These results are in line with previous observations in other Norwegian fjords (Skjæraasen et al. 2011). Meager et al. (2011) suggested that farmed cod will have a lower survival in the wild due to weaker anti-predator responses than wild cod. According to Sverdrup at al. (2011), farmed cod also have lower competitive capacity than their wild relatives. This would tend to reduce an introgression impact from escapees, which would depend on survival until the spawning season, and on competitive fitness in the reproduction process. In the first escape incident in December 2009 the majority of individuals were spawning (stage 3) (Fig. 3), which is well before the natural spawning time in March-May. For the second escape incident, the farmed cod were either maturing (stage 2) or spent (stage 4) (Fig. 3). Since the escape was 7 mo prior to the peak spawning in April, it is possible that this batch were in sync with the natural spawning time. However, the low survival/presence indicated by recapture rates makes it less likely that a large part of the escaped cod survived until the natural spawning time in the fjord. Concerning escapees which might have survived until the natural spawning season, several studies have shown that escaped farmed cod can be present on spawning grounds (Wroblewski et al. 1996, Uglem et al. 2008, Skjæraasen et al. 2011, Jørstad et al. 2013), and that farmed cod thus have the potential to participate in the spawning (Meager et al. 2009, 2010, Skjæraasen et al. 2010). However, while it has been suggested that farmed females may effectively take part in the natural spawning, farmed males may show limited success based on sperm characteristic, morphology and behaviour (Skjæraasen et al. 2008, 2009, 2010). Therefore, to the extent that escaped farm cod have survived and participated in natural spawning in the Trondheimsfjord in this study, the genetic effect of this would not be fully proportional to their nominal numbers. The possibility that farmed eggs, larvae and adult might have left the fjord and caused some degree of genetic impact outside the fjord was not investigated in this study. 


\section{CONCLUSIONS}

This study on potential interactions between farmed and wild cod in the Trondheimsfjord after extensive pen spawning and massive escape events did not leave robust evidence of a genetic introgression from farmed cod to the local wild cod stock. This result does not exclude the possibility that an introgression did take place, but that it was either cleansed rapidly by natural selection or was too small to be detected by the markers used. Also, a genetic signature of introgression might have been weakened by the concealing effects at some of the genetic markers due to opposite impacts from 2 different batches of farmed cod with different genetic characteristics. The time of the net-pen spawning of farmed cod was found to be out of phase with the natural annual cod spawning and plankton production cycle in the fjord, and the larvae from pen spawning may thereby have suffered mass deaths. An expected downstream transport of the pelagic eggs, larvae and codlings out of the fjord with the estuarine circulation would further reduce local genetic impact. Tagging-recapture results indicated that escaped farmed cod might not have survived long enough, and/or were not tuned to participate effectively in natural spawning. The summed effects of these factors may explain the apparent lack of genetic effects on the local wild cod stock.

Acknowledgements. We are grateful to Kathrine Michalsen at IMR for administration of the tagging reports, and to the manager and CEO of the cod farm Frengen Havbruk for cooperation. The crew on board RV Gunnerus of the Norwegian University of Science and Technology (NTNU) is acknowledged for skilled and wholehearted efforts in the field work. This project was part of the research program iCoast funded by the Norwegian Research Council (project number 122429) and the Norwegian Research Council project ECOCOAST: Kystøkosystemer i endring, and part of the $\mathrm{PhD}$ thesis of R.V. which were funded by the Faculty of Science and Technology at NTNU, Trondheim, Norway. Additional financial support was provided by the PreventEscape EU-project (project number 226885).

\section{LITERATURE CITED}

Aebersold PB, Winans GA, Teel DJ, Milner GB, Utter F (1987) Manual for starch gel electrophoresis: a method for the detection of genetic variation. NOAA Tech Rep NMFS 61

Antao T, Lopes A, Lopes R, Beja-Pereira A, Luikart G (2008) LOSITAN: A workbench to detect molecular adaptation based on a $F_{\mathrm{ST}^{-}}$-outlier method. BMC Bioinformatics 9:323

Baskett ML, Burgess SC, Waples RS (2013) Assessing strategies to minimize unintended fitness consequences of aquaculture on wild populations. Evol Appl 6:1090-1108
Bekkevold D, Hansen MM, Nielsen EE (2006) Genetic impact of gadoid culture on wild fish populations: predictions, lessons from salmonids, and possibilities for minimizing adverse effects. ICES J Mar Sci 63:198-208

$>$ Brooker AL, Cook D, Bentzen P, Wright JM, Doyle RW (1994) Organization of microsatellites differs between mammals and cold-water teleost fishes. Can J Fish Aquat Sci 51:1959-1966

Cushing DH (1990) Plankton production and year-class strength in fish populations: an update of the match/mismatch hypothesis. In: Blaxter JHS, Southward AJ (eds) Advances in Marine Biology, Vol 26. Academic Press, Suffolk, p 249-293

Dahl K (1899) Beretning om fiskeriundersøgelser i og om Trondhjemsfjorden 1898. K Norske Vidensk Selskab Skr 10:1-60

Dahle G, Jørstad KE, Rusaas HE, Otterå H (2006) Genetic characteristics of broodstock collected from four Norwegian coastal cod (Gadus morhua) populations. ICES J Mar Sci 63:209-215

Delghandi M, Mortensen A, Westgaard JI (2003) Simultaneous analysis of six microsatellite markers in Atlantic cod (Gadus morhua): a novel multiplex assay system for use in selective breeding studies. Mar Biotechnol (NY) 5: 141-148

Eiríksson GM, Árnason E (2013) Spatial and temporal microsatellite variation in spawning Atlantic cod, Gadus morhua, around Iceland. Can J Fish Aquat Sci 70:1151-1158

Ekli PH (1997) Årsklasseundersøkelser 1963-1994 hos torsk (Gadus morhua L.) I Trondheimsfjorden. Candidatus scientarium in Marine biology, Norwegian University of Science and Technology, Trondheim

> Estoup A, Rousset F, Michalakis Y, Cournet JM, Adriamanga M, Guyomard R (1998) Comparative analysis of microsatellite and allozyme markers: a case study investigating microgeographic differentiation in brown trout (Salmo trutta). Mol Ecol 7:339-353

$>$ Evanno G, Regnaut S, Goudet J (2005) Detecting the number of clusters of indiviudals using the software STRUCTURE: a simulation study. Mol Ecol 14:2611-2620

Fevolden SE, Pogson GH (1997) Genetic divergence at the synaptophysin (Syp I) locus among Norwegian coastal and north-east Arctic populations of Atlantic cod. J Fish Biol 51:895-908

Fevolden SE, Westgaard JI, Christiansen JS (2009) Farming of Atlantic cod Gadus morhua in the vicinity of major spawning sites for Norwegian coastal cod populationsis it hazardous? ICES CM 2009/Q:18 poster, ICES, Copenhagen

> Glover KA (2010) Forensic identification of fish farm escapees: the Norwegian experience. Aquacult Environ Interact 1:1-10

> Glover KA, Dahle G, Westgaard JI, Johansen T, Knutsen H, Jørstad KE (2010) Genetic diversity within and among Atlantic cod (Gadus morhua) farmed in marine cages: a proof-of-concept study for the identification of escapees. Anim Genet 41:515-522

> Glover KA, Dahle G, Jørstad KE (2011) Genetic identification of farmed and wild Atlantic cod, Gadus morhua, in coastal Norway. ICES J Mar Sci 68:901-910

> Goudet J (2005) HIERFSTAT, a package for R to compute and test hierarchical F-statistics. Mol Ecol Notes 5: 184-186

Hubisz MJ, Falush D, Stephens M, Pritchard JK (2009) Inferring weak population structure with the assistance of 
sample group information. Mol Ecol Resour 9:1322-1332

Jacobson P (1983) Physical Oceanography of the Trondheimsfjord. Geophys Astrophys Fluid Dyn 26:3-26

> Jørstad KE, van der Meeren T, Paulsen OI, Thomsen T, Thorsen A, Svåsand T (2008) 'Escapes' of eggs from farmed cod spawning in net pens: recruitment to wild stocks. Rev Fish Sci 16:285-295

Jørstad KE, Otterå $H$, van der Meeren T, Dahle G, Paulsen OI, Bakke G, Svåsand T (2013) Genetic marking of farmed Atlantic cod (Gadus morhua L.) and detection of escapes from a commercial cod farm. ICES J Mar Sci 71: 574-584

- Karlsson S, Mork J (2003) Selection induced variation at the pantophysin locus (Panl) in a Norwegian fjord population of cod (Gadus morhua L.). Mol Ecol 12: 3265-3274

Karlsson S, Mork J (2005) Deviation from Hardy-Weinberg equilibrium, and temporal instability in allele frequencies at microsatellite loci in a local population of Atlantic cod. ICES J Mar Sci 62:1588-1596

Knutsen H, Jorde PE, Andre C, Stenseth NC (2003) Finescaled geographical population structuring in a highly mobile marine species: the Atlantic cod. Mol Ecol 12: 385-394

Kruskal WH, Wallis WA (1952) Use of ranks in one-criterion variance analysis. J Am Stat Assoc 47:583-621

Kunz K (2011) Genetics of farmed and wild cod (Gadus morhua L.) in the Trondheimsfjord, Norway. Diploma thesis. Darmstadt University of Technology, Darmstadt

> Larsson LC, Laikre L, Palm S, Andre C, Carvalho GR, Ryman N (2007) Concordance of allozyme and microsatellite differentiation in a marine fish, but evidence of selection at a microsatellite locus. Mol Ecol 16:1135-1147

McDonald JH (2009) Handbook of biological statistics (2nd edn) Sparky House Publishing, Baltimore, MD

$>$ Meager JJ, Skjæraasen JE, Fernö A, Karlsen Ø, Løkkeborg S, Michalsen K, Utskot SO (2009) Vertical dynamics and reproductive behaviour of farmed and wild Atlantic cod Gadus morhua. Mar Ecol Prog Ser 389:233-243

Meager JJ, Skjæraasen JE, Fernö A, Løkkeborg S (2010) Reproductive interactions between fugitive farmed and wild Atlantic cod (Gadus morhua) in the field. Can J Fish Aquat Sci 67:1221-1231

Meager JJ, Rodewald P, Domenici P, Ferno A, Jarvi T, Skjaeraasen JE, Sverdrup GK (2011) Behavioural responses of hatchery-reared and wild cod Gadus morhua to mechano-acoustic predator signals. J Fish Biol 78: 1437-1450

Miller KM, Le KD, Beacham TD (2000) Development of triand tetranucleotide repeat microsatellite loci in Atlantic cod (Gadus morhua). Mol Ecol 9:238-239

Moe H, Dempster T, Sunde LM, Winther U, Fredheim A (2007) Technological solutions and operational measures to prevent escapes of Atlantic cod (Gadus morhua) from sea cages. Aquacult Res 38:91-99

Mork J (1976) Populasjonsstudier av torsk (Gadus morhua Linné) fra indre Trondheimsfjord. Candidatus realium in Marine zoology, Norwegian University of Science and Technology, Trondheim

Mork J, Giæever M (1999) Genetic structure of cod along the coast of Norway: results from isozyme studies. Sarsia 84: 157-168

> Mork J, Sundnes G (1985) O-group cod (Gadus morhua) in captivity: differential survival of certain genotypes. Helgol Meersunters 39:63-70
Mork J, Giskeødegård R, Sundnes G (1980) LDH gene frequencies in cod samples from two locations on the Norwegian coast. J Cons Int Explor Mer 39:110-113

Mork J, Reuterwall C, Ryman N, Ståhl G (1982) Genetic variation in Atlantic cod (Gadus morhua L.): a quantitative estimate from a Norwegian coastal population. Hereditas 96:55-61

Mork J, Solemdal P, Sundes G (1983) Identification of marine fish eggs: a biochemical genetics approach. Can J Fish Aquat Sci 40:361-369

Mork J, Ryman N, Ståhl G, Utter F, Sundnes G (1985) Genetic variation in Atlantic cod (Gadus morhua) throughout its range. Can J Fish Aquat Sci 42:1580-1587

Nielsen EE, Hansen MM, Meldrup D (2006) Evidence of microsatellite hitch-hiking selection in Atlantic cod (Gadus morhua L.): implications for inferring population structure in nonmodel organisms. Mol Ecol 15:3219-3229

Nielsen EE, Wright PJ, Hemmer-Hansen J, Poulsen NA, Gibb IM, Meldrup D (2009) Microgeograpichal population structure of cod Gadus morhua in the North sea and west of Scotland: the role of sampling loci and individuals. Mar Ecol Prog Ser 376:213-225

> Nordeide JT, Johansen SD, Jørgensen TE, Karlsen BO, Moum T (2011) Population connectivity among migratory and stationary cod Gadus morhua in the Northeast Atlantic-a review of 80 years of study. Mar Ecol Prog Ser 435:269-283

Norwegian Directorate of Fisheries (2009) Rapporterte rømninger til Fiskeridirektoratet. Directorate of Fisheries, Bergen. www.fiskeridir.no/Akvakultur/Statistikkakvakultur/Roemmingsstatistikk

- O'Reilly PT, Canino KM, Bailey KM, Bentzen P (2000) Isolation of twenty low stutter di- and tetranucleotide microsatellites for population analyses of walleye pollock and other gadoids. J Fish Biol 56:1074-1086

Peakall R, Smouse P (2006) GENALEX 6: genetic analysis in excel. Population genetic software for teaching and research. Mol Ecol Notes 6:288-295

Peakall R, Smouse P (2012) GENALEX 6.5: genetic analysis in excel. Population genetic software for teaching and reserach-an update. Bioinformatics 28:2537-2539

Pogson GH, Fevolden SE (2003) Natural selection and the genetic differentiation of coastal and Arctic populations of the Atlantic cod in northern Norway: a test involving nucleotide sequence variation at the pantophysin (PanI) locus. Mol Ecol 12:63-74

> Poulsen NA, Nielsen EE, Schierup MH, Loeschcke V, Gronkjaer P (2006) Long-term stability and effective population size in North Sea and Baltic Sea cod (Gadus morhua). Mol Ecol 15:321-331

> Pritchard JK, Stephens M, Donnely P (2000) Inference of population structure using multilocus genotype data. Genetics 155:945-959

Puckrin OA, Purchase CF, Trippel EA (2013) Using purposeful inbreeding to reduce outbreeding depression caused by escaped farmed Atlantic cod. Aquacult Environ Interact 4:207-221

Raymond M, Rousset F (1995) Genepop (version 1.2): population genetics software for exact tests and ecumenicism. J Hered 86:248-249

> Rice WR (1989) Analyzing tables of statistical tests. Evolution 43:223-225

Rollefsen G (1933) The otoliths of the cod: preliminary report. Reports on Norwegian Fisheries and Marine Investigations, Vol 4. Griegs, Bergen 
Rousset F (2008) GENEPOP'007: a complete reimplementation of the genepop software for Windows and Linux. Mol Ecol Resour 8:103-106

Ryman N, Palm S (2006) POWSIM: a computer program for assessing statistical power when testing for genetic differentiation. Mol Ecol Notes 6:600-602

Ryman N, Palm S, André C, Carvalho GR, and others (2006) Power for detecting genetic divergence: differences between statistical methods and marker loci. Mol Ecol 15:2031-2045

Salze G, Tocher DR, Roy WJ, Robertson DA (2005) Egg quality determinants in cod (Gadus morhua L.): egg performance and lipids in eggs from farmed and wild broodstock. Aquacult Res 36:1488-1499

Sarvas TH, Fevolden SE (2005) Pantophysin (Pan I) locus divergence between inshore $v$. offshore and northern $V$. southern populations of Atlantic cod in the north-east Atlantic. J Fish Biol 67:444-469

Sivertsen E (1935) Torskens gyting. Med særlig henblikk på den årlige cyklus i generasjonsorganenes tilstand. Reports on Norwegian Fisheries and Marine Investigations, Vol 4. Griegs, Bergen

> Skarstein TH, Westgaard JL, Fevolden SE (2007) Comparing microsatellite variation in north-east Atlantic cod (Gadus morhua L.) to genetic structuring as revealed by the Pantophysin (Pan I). J Fish Biol 70:271-290

Skjæraasen JE, Meager JJ, Karlsen Ø (2008) The expression of secondary sexual characteristics in recruit- and repeat-spawning farmed and wild Atlantic cod (Gadus morhua). ICES J Mar Sci 65:1710-1716

Skjæraasen JE, Mayer I, Meager JJ, Rudolfsen G, Karlsen Ø, Haugland T, Kleven O (2009) Sperm characteristics and competitive ability in farmed and wild cod. Mar Ecol Prog Ser 375:219-228

Skjæraasen JE, Meager JJ, Karlsen Ø, Mayer I, Dahle G, Rudolfsen G, Fernö A (2010) Mating competition between farmed and wild cod Gadus morhua. Mar Ecol Prog Ser 412:247-258

Skjæraasen JE, Meager JJ, Karlsen Ø, Hutchings JA, Fernö A (2011) Extreme spawning-site fidelity in Atlantic cod. ICES J Mar Sci 68:1472-1477

Statistics Norway (2013) Aquaculture; sales of slaughtered fish for food. Quantity, by fish species and county. https: //www.ssb.no (accessed October 2014)

Stenvik J, Wesmajervi MS, Damsgård B, Delghandi M (2006) Genotyping of pantophysin I (Pan I) of Atlantic cod (Gadus morhua L.) by allele-specific PCR. Mol Ecol Notes 6:272-275

Sundnes G (ed) (1980) Beitstadfjordprosjektet, sluttrapport. TBS rapport. Norwegian Univeristy of Science and Technology, Trondheim

Sverdrup GK, Meager JJ, Fernö A, Skjæraasen JE, Rodewald P, Salvanes AGV, Järvi T (2011) Territorial and

Editorial responsibility: Ian Fleming,

St. John's, Newfoundland and Labrador, Canada agonistic interactions between farmed and wild cod (Gadus morhua). Aquacult Res 42:1539-1548

Swenander G (1906) Bidrag til känndomen om Trondheimsfjordens fiskar. K Norske Vidensk Selskab Skr 9:1-112

$>$ Takezaki N, Nei M, Tamura K (2014) POPTREEW: web version of POPTREE for constructing population trees from allele frequency data and computing some other quantities. Mol Biol Evol 31:1622-1624

Tamura K, Stecher G, Peterson D, Filipski A, Kumar S (2013) MEGA6: molecular evolutionary genetics analysis version 6.0. Mol Biol Evol 30:2725-2729

Truett GE, Heeger P, Mynatt RL, Truett AA, Walker JA, Warman ML (2000) Preparation of PCR-quality mouse genomic DNA with hot sodium hydroxide and Tris (HotSHOT). BioTechniques 29:52-54

Uglem I, Bjørn PA, Dale T, Kerwath S and others (2008) Movements and spatiotemporal distribution of escaped farmed and local wild Atlantic cod (Gadus morhua L.). Aquacult Res 39:158-170

Uglem I, Knutsen Ø, Kjesbu OS, Hansen ØJ, and others (2012) Extent and ecological importance of escape through spawning in sea-cages for Atlantic cod. Aquacult Environ Interact 3:33-49

Van Oosterhout C, Hutchinson WF, Wills DM, Shipley P (2004) Micro-Checker: software for identifying and correcting genotyping errors in microsatellite data. Mol Ecol Notes 4:535-538

> Waples RS (1998) Separating the wheat from the chaff: patterns of genetic differentiation in high gene flow species. J Hered 89:438-450

Waples RS (2015) Testing for Hardy-Weinberg proportions: Have we lost the plot? J Hered 106:1-9

> Wennevik V, Jorstad KE, Dahle G, Fevolden SE (2008) Mixed stock analysis and the power of different classes of molecular markers in discriminating coastal and oceanic Atlantic cod (Gadus morhua L.) on the Lofoten spawning grounds, Northern Norway. Hydrobiologia 606:7-25

Wesmajervi MS, Westgaard JI, Delghandi M (2006) Evaluation of a novel pentaplex microsatellite marker system for paternity studies in Atlantic cod (Gadus morhua L.). Aquacult Res 37:1195-1201

> Westgaard JI, Fevolden SE (2007) Atlantic cod (Gadus morhua L.) in inner and outer coastal zones of Northern Norway display divergent genetic signature at nonneutral loci. Fish Res 85:306-315

Wright S (1978) Evolution and the genetics of population, variability within and among natural populations, Vol 4. University of Chicago Press, Chicago, IL

> Wroblewski JS, Smedbol RK, Taggart CT, Goddard SV (1996) Movements of farmed and wild Atlantic cod (Gadus morhua) released in Trinity bay, Newfoundland. Mar Biol 124:619-627

Submitted: March 2, 2015; Accepted: October 12, 2015

Proofs received from author(s): November 13, 2015 